już we wstępie. Świadczy to z całą pewnościa o wysokiej erudycji badaczy, doskonale orientujących się w istniejacych źródłach i umiejętnie je wykorzystujacych.

Trudno jest w kilku zdaniach przedstawić całość problematyki poruszanej przez autorów prezentowanej publikacji. Niemożliwe jest także w krótkim omówieniu wskazanie wszystkich ważnych $\mathrm{i}$ istotnych zagadnień. Jednak uważny czytelnik z pewnością dostrzeże, iż prezentowana praca stanowi nie tylko istotny akcent w badaniach nad dzieckiem, ale przede wszystkim ważny głos w badaniach nad rodzina, co sprawia, że praca pod wieloma względami jest wyjątkowa i nowatorska.

W podsumowaniu zaznaczyć należy, iż prezentowany zbiór nie wyczerpuje problematyki, a jedynie stanowi kolejny etap w procesie tworzenia pełnego obrazu dziejów dziecka i jego wy chowania $\mathrm{w}$ XIX i początkach XX wieku na ziemiach polskich.

Autorzy stawiaja nowe problemy badawcze, co pozwala oczekiwać kontynuacji badań w tym kierunku, zwłaszcza, że jak słusznie podkreślają redaktorzy publikacji, jest $w$ tej kwestii jeszcze wiele do zrobienia, a badaniami należałoby objąć zarówno realia funkcjonowania dziecka w rodzinie i społeczeństwie, działania opiekuńczo-wy- chowawcze oraz refleksję nad dzieciństwem i pracę opiekuńczo-wychowawczą w różnych środowiskach $^{5}$.

Grazyna Kartowska

1 Warto podkreślić, iż przedstawiony w pracy zbiór artykułów był impulsem do zorganizowania konferencji naukowej pod tożsamym tytulem, co prezentowana publikacja. Konferencja zorganizowana $z$ inicjatywy Katedry Historii Edukacji i Wychowania w Rodzinie AB, Zakładu Historii Myśli i Doktryn Pedagogicznych AB, a także przy współudziale Zakładu Historii Wychowania UAM i Wyższej Szkoly Informatyki i Ekonomii TWP w Olsztynie, odbyła się w dniach 24-26 czerwca 2003 roku w Pieczyskach.

2 Problematyka rodziny znalazła swe opracowanie m.in. w pracach: Wychowanie $w$ rodzinie od starozytnosici po wiek $X X$, pod red. J. Jundziłła, Bydgoszcz 1994; Rodzina jako środowisko wychowawcze $w$ czasach nowozytnych, pod red. K. Jakubiaka, Bydgoszcz 1995; a także w zbiorze studiów pt. Wychowanie $w$ rodzinie od schytku XVIII do potowy XX wieku, pod red. K. Jakubiaka i A. Winiarza, Bydgoszcz 2000.

${ }^{3}$ Dziecko $w$ rodzinie $i$ spoteczenistwie. Dzieje nowożytne, pod red. K. Jakubiaka i W. Jamrożka, t. II, Bydgoszcz 2002, s. 16.

4 Ibidem, s. $16-17$.

5 Ibidem, s. 16.

\title{
Edukacja - państwo - naród w Europie Środkowej i Wschodniej w XIX i XX wieku, pod redakcja Aleksandry Bilewicz, Ryszarda Gładkiewicza i Stefanii Walasek, Uniwersytet Wrocławski - Instytut Pedagogiki, Centrum Badań Ślaskoznawczych i Bohe- mistycznych, Wrocław 2002, ss. 456
}

XIX i XX wiek był dla Polaków okresem wielkich wzlotów i upadków. Polska słaba, gwałcona, niszczona i grabiona, zawsze potrafiła przetrwać wszystkie przeciwności losu, aby w najmniej oczekiwanym momencie powstać i pokazać się światu. Było to zasługa przede wszystkim każdego Polaka, który w swoim domu kultywowal ojczysty jezzyk, zwyczaje i kulturę. Nie bez znaczenia pozostaje $w$ tym wszystkim szkoła, która bez względu na to czy była tajna, półlegalna czy legalna, zawsze dawała i daje możliwości walki o lepsze jutro.

Prezentowana książka jest efektem zorganizowanej przez Centrum Badań Ślaskoznawczych i Bohemistycznych, w dniach 6-8 maja 2001 roku, międzynarodowej konferencji w Polanicy Zdroju dotyczacej „Oświaty i szkoły narodów bez państwa". Praca ta jest zbiorem 36 referatów zarówno o charakterze analitycznym jak i syntetycznym, dotyczących historii oświaty 
w Europie Środkowej i Wschodniej w XIX i XX wieku. Czytelnik możne podzielić je na trzy części. Pierwsza z nich jest najbardziej obszerna. Zawiera 23 referaty dotyczace oświaty pod zaborami. Istnieja w niej jednak dość znaczne dysproporcje. Najwięcej uwagi poświęcono Galicji, z kolei zabór pruski potraktowany jest praktycznie „po macoszemu".

Pierwsze trzy referaty można potraktować jako wprowadzajace do problemu. Stefania Walasek przedstawiła polskie szkolnictwo i oświatę w XIX i na poczatku XX wieku, kiedy to praktycznie Polska przez 123 lata nie istniała na żadnej mapie świata. Nie przeszkodziło to jednak Polakom, a wręcz odwrotnie, pobudziło ich jeszcze mocniej, we wszystkich trzech zaborach, do walki o polskie szkoły, nauczycieli, podręczniki, a przede wszystkim o polski język, bowiem zdawano sobie doskonale sprawę $\mathrm{z}$ tego, że oświata jest niezbędna do skutecznej walki o odbudowę i zreformowanie państwa oraz do zachowania polskiej kultury i obyczajów.

Józef Brynkus swój artykuł poświęcił rozumieniu świadomości narodowej Polaków w XIX wicku. Finalnie porównał nasza (jako narodu) świadomość z mentalnością innych nacji (tu za przykład podał Hiszpanów). Jedyne, według Brynkusa, co nas Polaków wyróżnia spośród innych obywateli świata, to mesjanizm, czyli powszechne przekonanie, że jesteśmy narodem wybranym, który pełnił i ma do spełnienia wielką rolę.

Dopełnieniem tego jest artykuł ks. Edwarda Walewandera, który mówi o treściach wychowawczych $w$ nauczaniu parafialnym na ziemiach polskich $w$ drugiej połowie XIX wieku. Jest to jeden $\mathrm{z}$ dwóch referatów, który, choć w bardzo małej mierze, wspomina o ludziach niedostosowanych spolecznie.

Dalej przedstawiony jest dość spory cykl artykułów poświęconych różnym aspektom szkolnictwa w Galicji. Zawiera on referaty przedstawiajace sytuację szkoły polskiej, ukraińskiej i słowackiej w monarchii austro-węgierskiej. Ciekawym i godnym polecenia $w$ tej części jest artykuł Wandy Wojtkiewicz-Rok o organizacji szkolnictwa medycznego w Galicji Wschodniej w XVIII i XIX wieku. Pokazała ona, że pewną niewymierną korzyścia wcielenia ziem polskich do monarchii austriackiej był fakt, przynajmniej teoretycznie, poprawy stanu sanitarnego Galicji.
Problematyka walki o polską szkołę w Galicji poruszona została przez Lucynę Kudłę i Grażynę Pańko, które skupily się w swych rozważaniach na mlodzieży gimnazjalnej oraz Andrzeja Meissnera, który podją temat nauczycieli polskich. Natomiast Roman Baron poruszył ciekawą kwestię działalności Towarzystwa Szkoły Ludowej (TSL) na Kresach Ostrawskich na początku XX wieku. W początkowym okresie swej działalności TSL organizowała przede wszystkim kursy dla dorosłych analfabetów, jednak z biegiem czasu jej działalność zatoczyła szersze kręgi i stała się bardziej wszechstronna, bowiem zaczęto organizować placówki oświatowe dla dzieci i młodzieży od 3 do 19 lat. Ukrainka, Swietłana Łaba, zajęła się problematyką czasopism edukacyjnych we Wschodniej Galicji na przełomie XIX i XX wieku.

Tematyka dotycząca nacji ukraińskiej poruszana była nie tylko przez reprezentantów Ukrainy, ale również przez Polaków. Do tych pierwszych zaliczyć możemy Irinę Kurlak oraz Irinę Myszczyszyn, które podjęły problem kształtowania się tożsamości narodowej Ukraińców i procesu formowania się elit. Do drugich zaliczymy Jerzego Potocznego, który omówił sprawę elementarnej oświaty dorosłych i Barbarę Łuczyńska, która zajęła się udziałem nauczycieli szkół średnich w ruchu odrodzenia narodowego.

W części tej znalazły się również artykuły naszych południowych sasiadów. Jozef Pšenấk $\mathrm{z}$ Bratysławy przedstawił politykę władz zaborczych wobec walki Słowaków o szkołę narodową, natomiast Maria Marečková z Brna zajęła się współpracą czesko-słowacka w modernizacji szkoły narodowej pod koniec XIX wieku.

W części pierwszej można znaleźć nie tylko referaty o szkolnictwie polskim, ukraińskim czy słowackim, ale również dzięki Kazimierzowi Rędzińskiemu można pogłębić swoją wiedzę na temat roli świeckich szkół żydowskich w procesie integracji społecznej i kulturowej, a także zapoznać się z artykułem Adama Krzanowskiego odnośnie budzenia się świadomości narodowej w umysłach młodych skautów i harcerzy. Jest to artykuł godny polecenia, gdyż przybliża czytelnikowi przyczyny, dla których harcerstwo wzorujace się na angielskim skautingu Baden-Powella tak szybko i mocno przyjęło się i zakorzeniło na 
gruncie polskim, wypełniając tym lukę, która odczuwała młodzież polska.

Dalej zaprezentowane sa cztery referaty dotyczace Królestwa Polskiego. Dwa z nich, Ewy Kuli i Janiny Wołoczuk poruszaja kwestię nauczycieli. Natomiast Małgorzata Czapska podjęła problem średnich szkół prywatnych. Z kolei Małgorzata Stawiak zastanowiła się nad jakże ważna rola kobiet w wychowaniu patriotycznym. Matki, żony i córki były przez wiele lat niedoceniane, spychane na bok. Najważniejszy zawsze był mężczyzna, który, jak na niego przystało, bohatersko przelewajac krew i oddając życie walczył o wolność. Nikomu nawet przez myśl nie przyszło, że to właśnie na kobietach spoczywał obowiazek kultywowania tradycji polskich. Bez nich, bez ich trudu nie byłoby tych bohaterskich mężczyzn.

Problem kobiet został poruszony też przez Justynę Gulczyńską, która skupiła się głównie na wychowaniu narodowym dziewczat w zaborze pruskim.

Część druga, to okres II Rzeczypospolitej. Zawarta w niej jest problematyka mniejszości narodowych. Joanna Sadowska wzbogaciła tę część referatem o ustawie jędrzejewiczowskiej z 11 marca 1932 roku. Natomiast problem Żydów został poruszony przez Marię Meducką i Marzenę Pękowską. Pierwsza z nich zajęła się szkolnictwem żydowskim w latach 1918-1939 w dawnym województwie kieleckim. Z kolei Marzena Pękowska poruszyła jakże ważną i, niestety, zaniedbana tematykę dzieci specjalnej troski na przykładzie Żydowskiej Szkoły dla Głuchoniemych im. Izaaka Bardacha we Lwowie.

Znalazły się tu również referaty Karola Sanojca, który ukazał problem lojalności ukraińskich nauczycieli wobec Polski, Jaroslava Vakulika, który przedstawił szkołe czeską na Wołyniu i Eleonory Sapii-Drewniak, która omówiła problem dorosłych dokształcających się na kursach na Śląsku Opolskim.

Ostatnia czẹść można odnieść do współczesności. Jest to okres po II wojnie światowej do dnia dzisiejszego. W części tej znalazł się m.in. artykuł Edmunda Pecha, który przedstawił, podobnie jak Peter Kunze, szkolnictwo łużyckie w Niemczech, ( $z$ ta jednak różnica, że pierwszego $\mathrm{z}$ nich interesowały lata 1945-1990, natomiast drugiego pierwsza połowa XIX wieku). Paweł Jaworski skoncentrował się na przystosowaniach do rze- czywistości polskiej wzorów skandynawskich uniwersytetów ludowych.

W części tej nie zabrakło też autorów innej narodowości. Nada Babić i Stanislava Irowić zwróciły uwagę na ważną rolę edukacji, jaką ta pełni w społeczeństwie wielokulturowym. Natomiast Swietłana Kogut przedstawiła rolę pedagoga w procesie integracji mieszkańców zachodniej Ukrainy.

Sa w pracy dwa artykuly dotyczace prawa. Pierwszy z nich, Jolanty Szablickiej-Żak, dotyczy tematu ochrony mniejszości narodowych w systemie prawa międzynarodowego, $z$ kolei drugi z nich - Beaty Krawjec - pokazuje, w jaki sposób prawny Unia Europejska zadbała o ochronę prawa do edukacji dzieci z rodzin imigrantów.

Ostatni $z$ artykułów jest najbardziej kontrowersyjny i zmuszajacy do refleksji nad dzisiejszym „pędem" za postępami techniki. W XIX i na początku XX wieku Polacy walczyli nie tylko o polską szkołę, ale przede wszystkim o zachowanie swojej narodowości. Co nam przyniósł koniec $\mathrm{XX}$ wieku? $\mathrm{Na}$ to pytanie daje nam częściowo odpowiedź referat Jacka Z. Górnikiewicza, który pisze o możliwościach uczenia się na odległość za pomoca internetu. Łatwo można zgodzić się z autorem, że jest to łatwy, przydatny i bardzo szybki sposób zdobywania informacji i wiedzy. Trzeba przyznać rację, że DL via Internet jest ponad podziałami administracyjnymi, międzykulturowymi, psychologicznymi i biologicznymi, trudno jednak oprzeć się wrażeniu, mimo że nie to było celem autora, że złe korzystanie z dobrodziejstw współczesnej techniki może doprowadzić do stania się Robinsonem Crusoe, jednym spośród wielu tysięcy.

Podsumowujac, można śmiało powiedzieć, że omawiana książka jest interesująca pozycja, aczkolwiek nie wyczerpuje tematu do końca. Jest wiele kwestii, które nie zostały w niej poruszone. Brakuje pewnego ujednolicenia (dotyczy to również języka; artykuły niektórych zagranicznych autorów wydrukowane sa w językach, które trudno nazwać konferencyjnymi) i zachowania proporcji, co wynika z faktu, iż jest to zbiór referatów przygotowanych na konferencję naukowa. Jej wartość w znacznej mierze wzbogacaja liczne przypisy i indeks nazwisk (s. 439-453).

Sylwia Ewa Hubicka 